\title{
Study on soil analysis in ponds in the Sabang block areas, West Bengal, India
}

\author{
Uttam Kumar Maji ${ }^{1 *}$, Ranajit Kumar Khalua ${ }^{2}$, Kartik Maiti ${ }^{3}$ \\ ${ }^{1}$ Zoology. Uttam Kumar Maji, Balurghat B.Ed. College, WBUTTEPA, Balurghat, India \\ ${ }^{2}$ Zoology. Ranajit Kumar Khalua, Narajole Raj College, VU, Narajol, India \\ ${ }^{3}$ Zoology. Kartik Maiti, Raja N.L.K. Womens' College, VU, Medinipur, India \\ *Corresponding Author: majiuttam87@gmail.com, Phone No-9733752348
}

Available online at: www.isroset.org

Received: 05/Oct/2019, Accepted: 15/Oct/2019, Online: 31/Oct/2019

\begin{abstract}
Bacteria live in fresh water, soil, air and sea water. Bacteria have different nature in different zone. Thus periphyton bacteria has different characteristic in different zone. But I discussed in my topic soil analysis in fresh water ponds in Sabang block areas. I have done the experiment about one year in Sabang block areas. Soil collected by the bucket. This collected soil is collected from five ponds (Ghat pond, Dhara pond, Majari pond, Nandan pond \& Masanta pond) in Sabang block areas. There were two types of pond present Control pond and Experimental pond. In this pond was added the semidried cow dank. In this experiment we are followed the some methods. The pond bottom soil was analyzed for nitrogen, available phosphorus and available potassium following the standard methods of AOAC (1980). In all the experimental ponds before treatment however, after treatment the nitrogen level increased considerable. Phosphorus plays significant role in enhancing the productivity of pond. Potassium is not limiting factor and is not necessary to increase production.
\end{abstract}

Keywords: Soil analysis, nitrogen, phosphorus, potassium, ponds.

\section{INTRODUCTION}

This physic-chemical is changed in soil by the variable factors. Plankton develops by the physic-chemical changes in pond soil significantly. This change involves the low and high temperature in the water body. Low and high level of $\mathrm{pH}$ is changed by the physic-chemical process. Dissolved oxygen decides the fresh water quality in the ponds. Its' maintain the water health. Free carbon dioxide in the pond is changed in the water by every factor. Physic-chemical change the conductivity of water after and before use of bacterial suspension. Fish growth and fish quality depends on the before and after use of bacterial suspension, physicchemical quality and planktonic composition of the ponds. In Sabang block areas there are five ponds like Ghat pond (CP), Dhara pond (EP1), Majari pond (EP2), Nandan pond (EP3) and Masanta pond (EP4). All ponds are filled by the rainy water. In these ponds cultured the Indian major carps like catla, rohita, mrigala.

\section{RELATED WORK}

Living organism and nonliving organism are dissolved in fresh water. How many aliments and dissolved in fresh water recorded in this pond publication of Sarwar and Wazir, (1991) the physic chemical changes is in fresh water pond. There are main points is eutropications of the water body because the alkaline nature of the water and higher concentration of phosphorus and nitrate.

\section{METHODOLOGY}

Soil analysis:

The pond bottom soil was analyzed for nitrogen, available phosphorus and available potassium following the standard methods of AOAC (1980).

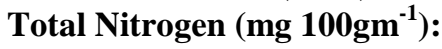

\section{Procedure:}

$10 \mathrm{gm}$ soil was taken in a distilled flask. Added $100 \mathrm{ml}$ $0.32 \% \mathrm{KMnO}_{4}$ and $120 \mathrm{ml}$ distilled water. Then added small amount of paraffin and $6-8$ glass beads and $80 \mathrm{ml} 2.5 \%$ $\mathrm{NaOH}$. Distil the solution and collect two distillate in $10 \mathrm{ml}$ $0.02(\mathrm{~N}) \mathrm{H}_{2} \mathrm{SO}_{4}$ is using mixed indicator in a $500 \mathrm{ml}$ conical flask. The distillate (approx. 200ml) titrated with $0.02(\mathrm{~N})$ $\mathrm{NaOH}$ solutions. The colour of the solution was radish violet to green end point light green. Simultaneously blank is trated $10 \mathrm{ml} 0.02(\mathrm{~N}) \mathrm{H}_{2} \mathrm{SO}_{4}$ and mixed indicator taken in a $500 \mathrm{ml}$ conical flask and titrate with $0.02(\mathrm{~N}) \mathrm{NaOH}-$ end point light green. $10 \mathrm{ml} 0.02(\mathrm{~N})$ oxlic acid and phenolphthalein indicator taken in $500 \mathrm{ml}$ conical flask and titrate with 0.02 (N) $\mathrm{NaOH}$ - end point light pink. 
Calculation: Nitrogen in soil $=\frac{(S-T) \times 1.4 \times N}{G}$

$\mathrm{S}=$ Blank liter value of $\mathrm{NaOH}$ in $\mathrm{ml}$

$\mathrm{T}=$ Sample titer value of $\mathrm{NaOH}$ solution

$\mathrm{N}=$ Normality of $\mathrm{NaOH}$ solution

$\mathrm{G}=$ Sample weight in gram.

Available Phosphorus $\left(\mathrm{mg} 100 \mathrm{gm}^{-1}\right)$ :

\section{Procedure:}

$25 \mathrm{ml}$ of Bray's extract was added with $10 \mathrm{gm}$. Soil in a 100 $\mathrm{ml}$. conical flask. After shaking for 2 minutes it was filtered. $10 \mathrm{ml}$. of the extract was taken in a $50 \mathrm{ml}$. volumetric flask and adjusted the $\mathrm{pH}$ of the solution by $4(\mathrm{~N}) \mathrm{HCl}$ and $4(\mathrm{~N})$ $\mathrm{NH}_{3}$ solution using 2: 4 dinitrophenol as indicator. $2 \mathrm{ml}$. of chloromolibodic acid, $20 \mathrm{ml}$ of distilled water was added. By adding $1 \mathrm{ml}$ of staneous chloride chloride solution in the solution and then blue colour developed. Then from the colorimeter at $660 \mu \mathrm{m}$ wave length, the reading was taken.

Calculation: Content of phosphorus in soil $=12.5 \times \mathrm{X} \mathrm{ppm}$. $\mathrm{X}=$ ppm of phosphorus in the colour solution.

\section{Available Potassium (mg 100gm $\left.{ }^{-1}\right)$ :}

Procedure: $10 \mathrm{gm}$ soil sample taken in $250 \mathrm{ml}$ beaker added $25 \mathrm{ml}$ distilled water. Then added $1 \mathrm{ml}$ conc. $\mathrm{H}_{2} \mathrm{SO}_{4}$ and shaker by glass rods for $3-4$ minutes. $100 \mathrm{ml}$ filtrate was taken in $100 \mathrm{ml}$ volumetric flask total soil was washed by $0.1(\mathrm{~N}) \mathrm{H}_{2} \mathrm{SO}_{4}$. Then potassium was measured by Flame photometer. The meter was standardized with $20 \mathrm{ppm} \mathrm{K}$ solution to 100 Galvanometer reading.

Calculation: Content of available potassium $(\mathrm{K})$ in soil $=10$ $\times \mathrm{X} \mathrm{ppm}$

$X=$ ppm of $K$ in the soil extract or filtrated i.e. $20 /$ $100 \times$ Galvanometer reading for filtrate.

\section{Location of ponds:}

\section{Ghat pond (Control pond)}

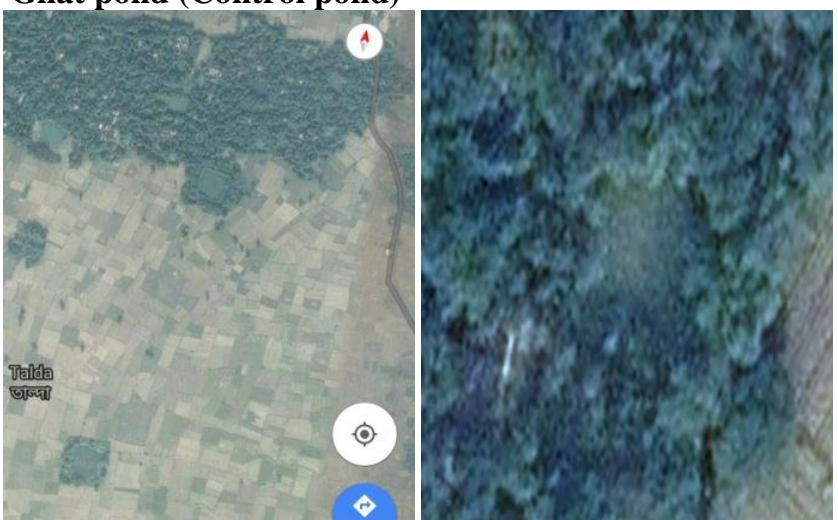

Image 1. Google earth map of Ghat pond in Sabang.

Talda is a village in Sabang Block, Paschim Medinipur District, West Bengal State. Talda is $70 \mathrm{~km}$ far from its district main city Medinipur. Nearest town is Kharagpur 45 $\mathrm{km}$ far from Talda village. Nearest railway station of this village is Balichak. Talda is $25 \mathrm{~km}$ far from its nearest station Balichak. Ghat pond (CP) is lying on estern side of the village. It is natural pond. Rain water enters from the surroundings into the pond. A canal is present estern side of the pond. People from the surround area discharge their kitchen waste directly into its water. Bamboo covers about $25 \%$ area of the land of the pond. Ghat pond covers an area of $1418 \mathrm{~m}^{2}$, peripheral area if the pond is $134 \mathrm{~m}$. and depth is 8 feet. Its exat geographical location is $\mathbf{2 2}^{\circ}{ }^{\prime} \mathbf{3 2 . 4 4 6 8}$ " $\mathrm{N}$ Latitude and $\mathbf{8 7}^{\circ} \mathbf{3 2}$ '29.5008” E Longitude and $13.5 \mathrm{~m}$ (Approx) above sea level.

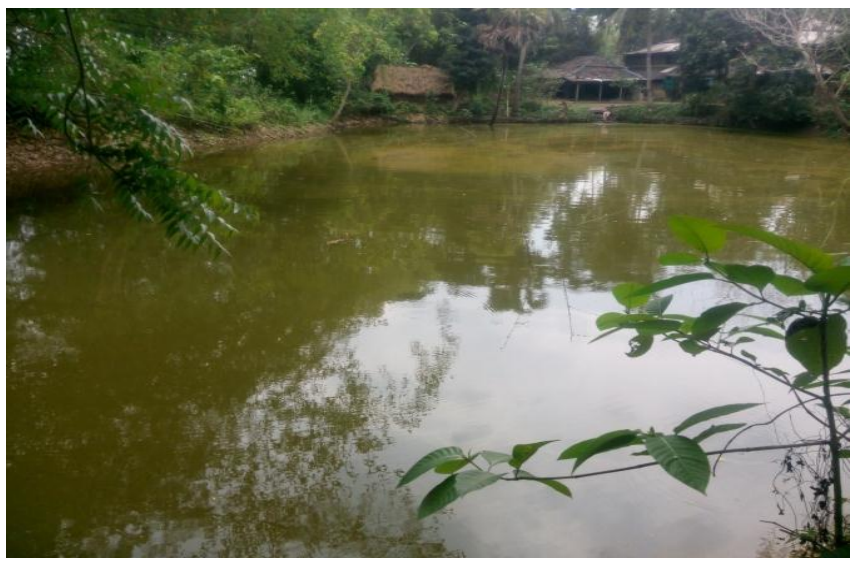

Image 2. Ghat pond.

Dhara pond (Experimental pond 1)

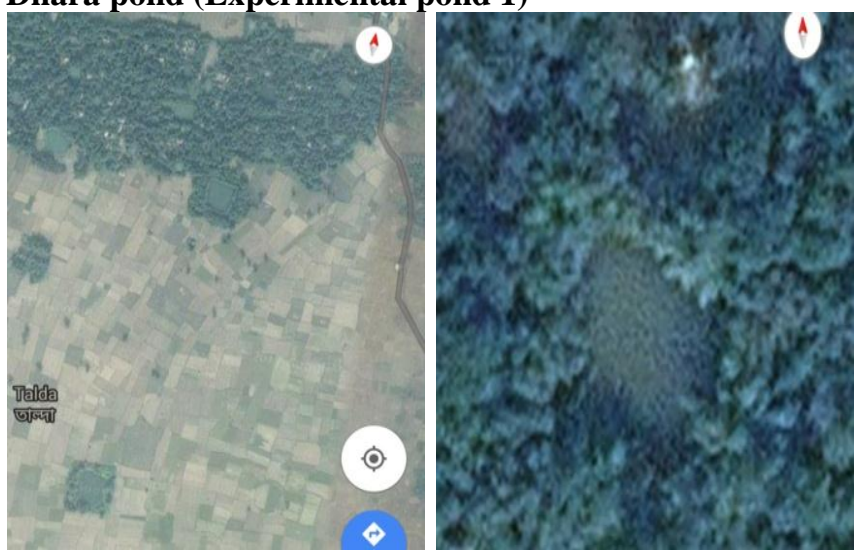

Image 3. Google earth map of Dhara pond in Sabang.

In district Paschim Medinipur, West Bengal the Talda village is situated in Sabang block area. Talda is present from Medinipur $70 \mathrm{~km}$ far. It is $45 \mathrm{~km}$ far from the Kharagpur. Dhara pond is lying on north-estern side of this pond. This pond is filled by rain water. Houses are present north and south side of the pond. People from the surround area discharge their kitchen waste directly into its water. Bamboo covers about $45 \%$ area of the land of the pond. Dhara pond (EP1) covers an area of $2674 \mathrm{~m}^{2}$, peripheral area if the pond is $184 \mathrm{~m}$. and depth is 10 feet. Its exat geographical location is 22 ${ }^{\circ}$ '36.1656" $\mathrm{N}$ Latitude and 87'32’29.3532'E Longitude and $13.6 \mathrm{~m}$ (Approx) above sea level. 


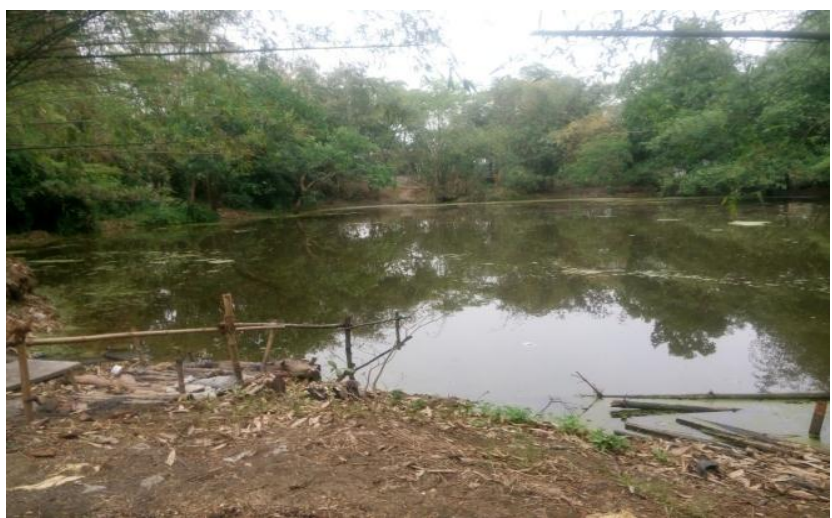

Image 4. Dhara pond.

\section{Majari pond (Experimental pond 2)}

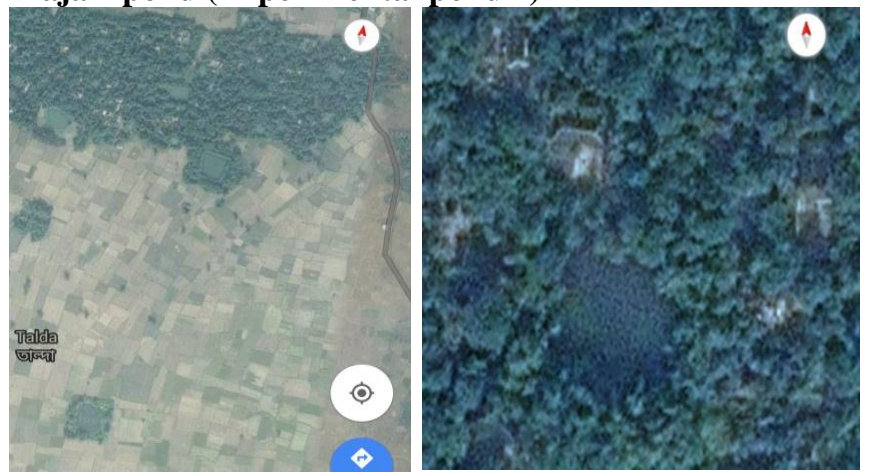

Image 5. Google earth map of Majari pond in Sabang.

Talda village is present in the Sabang, Paschim Medinipur, West Bengal. Nearest district town is Medinipur. Kharagpur is the nearest city. Majari pond (EP2) is situated middle position of the village. This pond filled by the rain water. Houses are present east, west and north side of the pond. People from the surround area discharge their kitchen waste directly into its water. Bamboo covers about $35 \%$ area of the land of the pond. Majari pond covers an area of $3605 \mathrm{~m}^{2}$, peripheral area if the pond is $213 \mathrm{~m}$. and depth is 10 feet. Its exat geographical location is $\mathbf{2 2}^{\circ} \mathbf{9}^{\prime} \mathbf{3 5 . 0 0 2 8}$ " $\mathrm{N}$ Latitude and 87'32'23.2728'"E Longitude and $13.6 \mathrm{~m}$ (Approx) above sea level.

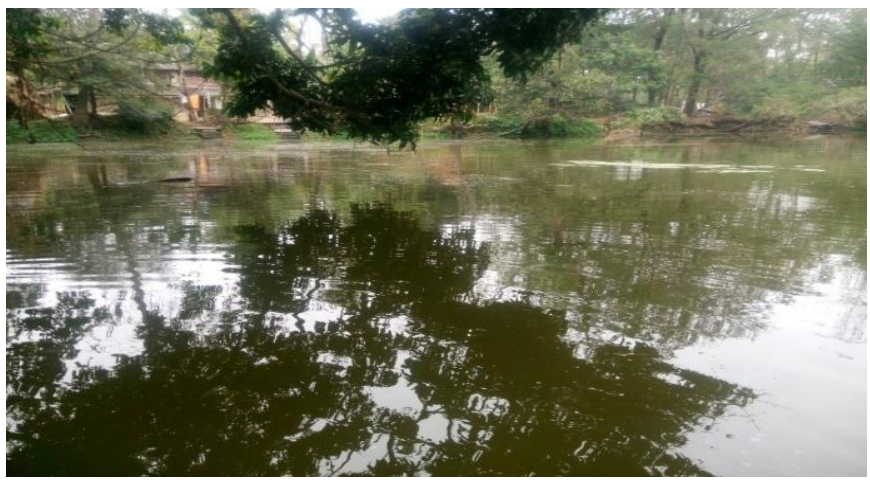

Image 6. Majari pond.

\section{Nandan pond (Experimental pond 3)}

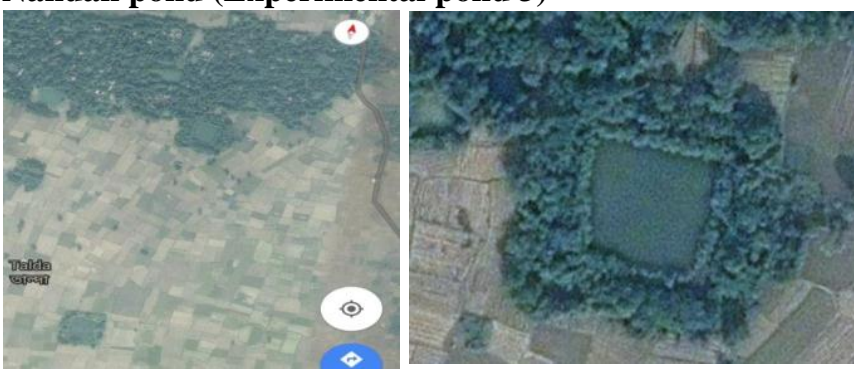

Image 7. Google earth map of Nandan pond in Sabang.

In West Bengal state Talda village is psesent. Talda village is present $70 \mathrm{~km}$ far from the district town. This natural pond filled by rainy water. Village persons' language is Bengali. Occupation is fishing of this village. Wetland field is present in this village. Beautification and flowering plant is present surrounding this pond. Pedy fields are present east, west and south side of the pond. Bamboo covers about 5\% area of the land of the pond. Nandan pond (EP3) covers an area of 4496 $\mathrm{m}^{2}$, peripheral area if the pond is $238 \mathrm{~m}$. and depth is 8 feet. Its exact geographical location is $\mathbf{2 2}^{\circ} \mathbf{9}^{\prime} \mathbf{2 7 . 0 5 0 4}$ 'N Latitude and $\mathbf{8 7}^{\circ} \mathbf{3 2}{ }^{\prime} \mathbf{2 0 . 9 3 2 8}$ 'E Longitude and $13.7 \mathrm{~m}$ (Approx) above sea level.

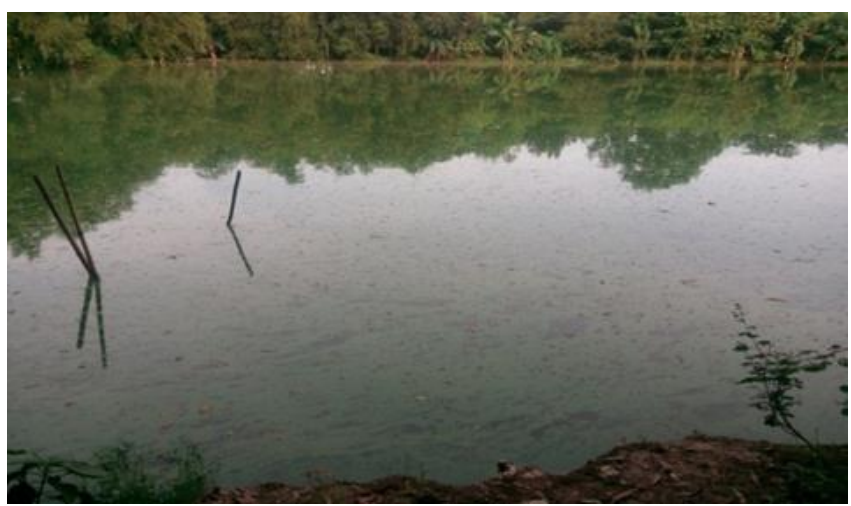

Image 8. Nandan pond.

\section{Masanta pond (Experimental pond 4)}

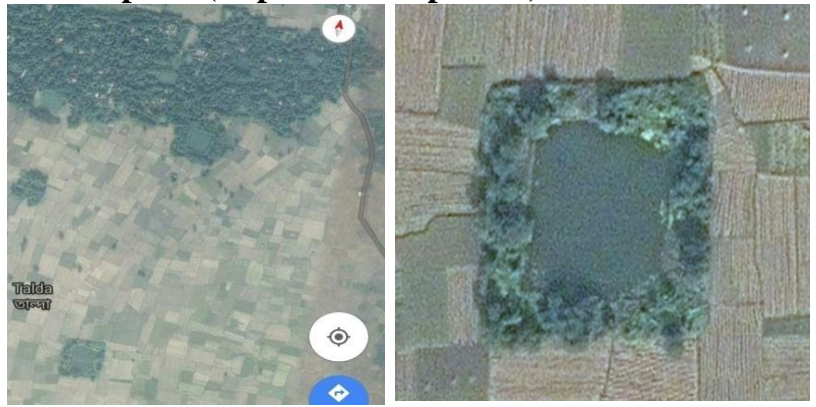

Image 9. Google earth pond of Masanta pond in Sabang.

In Sabang block area Masanta pond (EP4) is present. District town is Medinipur $70 \mathrm{~km}$ far from this village. Nearest town is Kharagpur and it is the rail way city. Sunlight is falled allover the pond. Pedy fields are present east, west, north 
and south side of the pond. Tree covers about $90 \%$ area of the land of the pond. Masanta pond (EP4) covers an area of $4577 \mathrm{~m}^{2}$, peripheral area if the pond is $240 \mathrm{~m}$. and depth is 20 feet. Its exact geographical location is $\mathbf{2 2}^{\circ} \mathbf{9}^{\prime} \mathbf{4 . 4 9 2 8}$ ' $\mathrm{N}$ Latitude and $\mathbf{8 7}^{\circ} \mathbf{3 2}$ '14.9352' $\mathrm{E}$ Longitude and $13.8 \mathrm{~m}$ (Approx) above sea level.

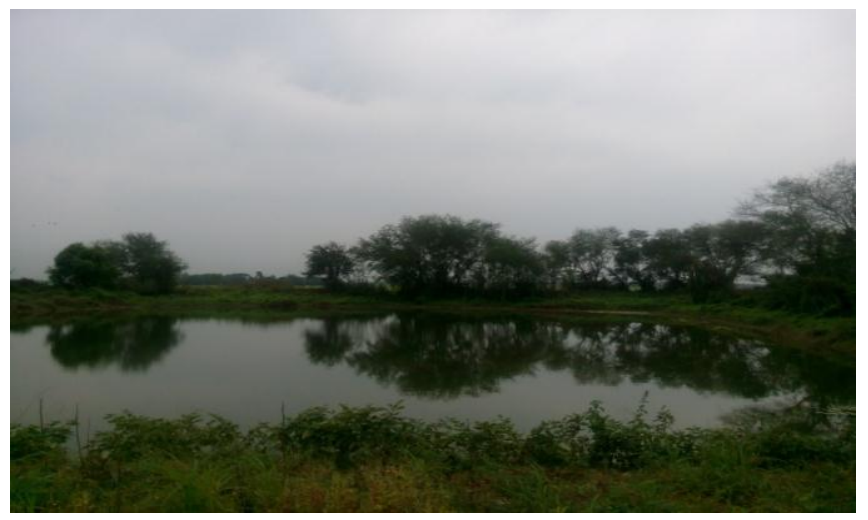

Image 10. Masanta pond.

\section{RESULTS AND DISCUSSION}

\section{Results of Total Nitrogen (mg $\left.100 \mathrm{gm}^{-1}\right)$ season 2015-} 2016:

In the month of July 2015 the total nitrogen was in CP pond 0.22 , EP1 pond 0.42 , EP2 pond $0.43, \mathrm{EP} 3$ pond $0.32 \& \mathrm{EP} 4$ pond 0.34. The total nitrogen in the month of August was in CP pond 0.22 , EP1 pond 0.42 , EP2 pond 0.42 , EP3 pond $0.32 \&$ EP4 pond 0.34 . In the month of September the total nitrogen was in CP pond 0.19 , EP1 pond 0.41 , EP2 pond $0.44, \mathrm{EP} 3$ pond $0.33 \& \mathrm{EP} 4$ pond 0.33 . The total nitrogen in the month of October was in CP pond 0.19, EP1 pond 0.32, $\mathrm{EP} 2$ pond 0.33 , EP3 pond $0.31 \& \mathrm{EP} 4$ pond 0.25 . In the month of November the total nitrogen was in CP pond 0.17, EP1 pond 0.37, EP2 pond $0.34, \mathrm{EP} 3$ pond $0.21 \&$ EP4 pond 0.21 . In the month of December 2015 the total nitrogen was in $\mathrm{CP}$ pond 0.18 , EP1 pond $0.37, \mathrm{EP} 2$ pond $0.37, \mathrm{EP} 3$ pond $0.19 \&$ EP4 pond 0.23 . The total nitrogen in the month of January 2016 was in CP pond 0.26, EP1 pond 0.35, EP2 pond 0.44 , EP3 pond $0.27 \&$ EP4 pond 0.33. In the month of February the total nitrogen was in CP pond 0.21 , EP1 pond $0.40, \mathrm{EP} 2$ pond 0.42 , EP3 pond 0.33 \& EP4 pond 0.33 . The total nitrogen in the month of March was in CP pond 0.29, EP1 pond 0.42 , EP2 pond 0.41 , EP3 pond 0.33 \& EP4 pond 0.34 . In the month of April the total nitrogen was in CP pond 0.29 , EP1 pond 0.35, EP2 pond 0.32, EP3 pond $0.37 \&$ EP4 pond 0.30 . The total nitrogen in the month of May 2016 was in $\mathrm{CP}$ pond $0.30, \mathrm{EP} 1$ pond $0.36, \mathrm{EP} 2$ pond $0.42, \mathrm{EP} 3$ pond $0.31 \&$ EP4 pond 0.41 . The average nitrogen in soil was $0.346 \mathrm{mg} 100 \mathrm{gm}-1$ in the month of July, 2015. In the month of August, 2015 the average nitrogen was 0.344. The average nitrogen was 0.34 in the month of September. In the month of October the average nitrogen was 0.28 . In the month of November the average nitrogen was 0.26 . The average nitrogen was 0.268 in the month of December, 2015. In the month of January, 2016 the average nitrogen was 0.33 . The average nitrogen was 0.338 in the month of February. In the month of March the average nitrogen was 0.358 . The average nitrogen was 0.326 in the month of April. In the month of May, 2016 the average nitrogen was 0.36 . The maximum average nitrogen was 0.36 in the month of May, 2016. In the month of November, 2015 the minimum average nitrogen was 0.26 . In Ghat pond (CP) the highest total nitrogen in soil was 0.30 in the month of May, 2016 and lowest total nitrogen was 0.17 in the month of November, 2015. In Dhara pond (EP1) the maximum total nitrogen in soil was 0.42 in the month of March, 2016 and minimum total nitrogen was 0.32 in the month of October, 2015. In Majari pond (EP2) the highest total nitrogen was 0.49 in the month of September and January and lowest number of total nitrogen was 0.32 in the month of April, 2016. In Nandan pond (EP3) maximum total nitrogen was 0.37 in the month of April and minimum total nitrogen was 0.19 in the month of December, 2015. In Masanta pond (EP4) the highest number of total nitrogen was 0.41 in the month of May and lowest number of total nitrogen was 0.21 in the month of November.

Season $(2015$ - 2016)

\begin{tabular}{|l|l|l|l|l|l|}
\hline Months & CP & EP1 & EP2 & EP3 & EP4 \\
\hline July & 0.22 & 0.42 & 0.43 & 0.32 & 0.34 \\
& \pm 0.0011 & \pm 0.0011 & \pm 0.0004 & \pm 0.0011 & \pm 0.0011 \\
\hline August & 0.22 & 0.42 & 0.42 & 0.32 & 0.34 \\
& \pm 0.0011 & \pm 0.0005 & \pm 0.0005 & \pm 0.0011 & \pm 0.0016 \\
\hline September & 0.19 & 0.41 & 0.44 & 0.33 & 0.33 \\
& \pm 0.0011 & \pm 0.002 & \pm 0.0004 & \pm 0.0004 & \pm 0.0011 \\
\hline October & 0.19 & 0.32 & 0.33 & 0.31 & 0.25 \\
& \pm 0.002 & \pm 0.0011 & \pm 0.02 & \pm 0.004 & \pm 0.0011 \\
\hline November & 0.17 & 0.37 & 0.34 & 0.21 & 0.21 \\
& \pm 0.0011 & \pm 0.0011 & \pm 0.02 & \pm 0.0011 & \pm 0.0005 \\
\hline
\end{tabular}

Table 1. Total Nitrogen $\left(\mathrm{mg} 100 \mathrm{gm}^{-1}\right)($ mean \pm S.E. $)$ 


\begin{tabular}{|l|l|l|l|l|l|}
\hline December & 0.18 & 0.37 & 0.37 & 0.19 & 0.23 \\
& \pm 0.0005 & \pm 0.005 & \pm 0.005 & \pm 0.027 & \pm 0.003 \\
\hline January & 0.26 & 0.35 & 0.44 & 0.27 & 0.33 \\
& \pm 0.023 & \pm 0.0011 & \pm 0.002 & \pm 0.0004 & \pm 0.017 \\
\hline February & 0.21 & 0.40 & 0.42 & 0.33 & 0.33 \\
& \pm 0.0004 & \pm 0.0004 & \pm 0.0005 & \pm 0.0011 & \pm 0.017 \\
\hline March & 0.29 & 0.42 & 0.41 & 0.33 & 0.34 \\
& \pm 0.0011 & \pm 0.0011 & \pm 0.0011 & \pm 0.0011 & \pm 0.0011 \\
\hline April & 0.29 & 0.35 & 0.32 & 0.37 & 0.30 \\
& \pm 0.0011 & \pm 0.005 & \pm 0.012 & \pm 0.0011 & \pm 0.0011 \\
\hline May & 0.30 & 0.36 & 0.42 & 0.31 & 0.41 \\
& \pm 0.0111 & \pm 0.0011 & \pm 0.0011 & \pm 0.0004 & \pm 0.003 \\
\hline
\end{tabular}
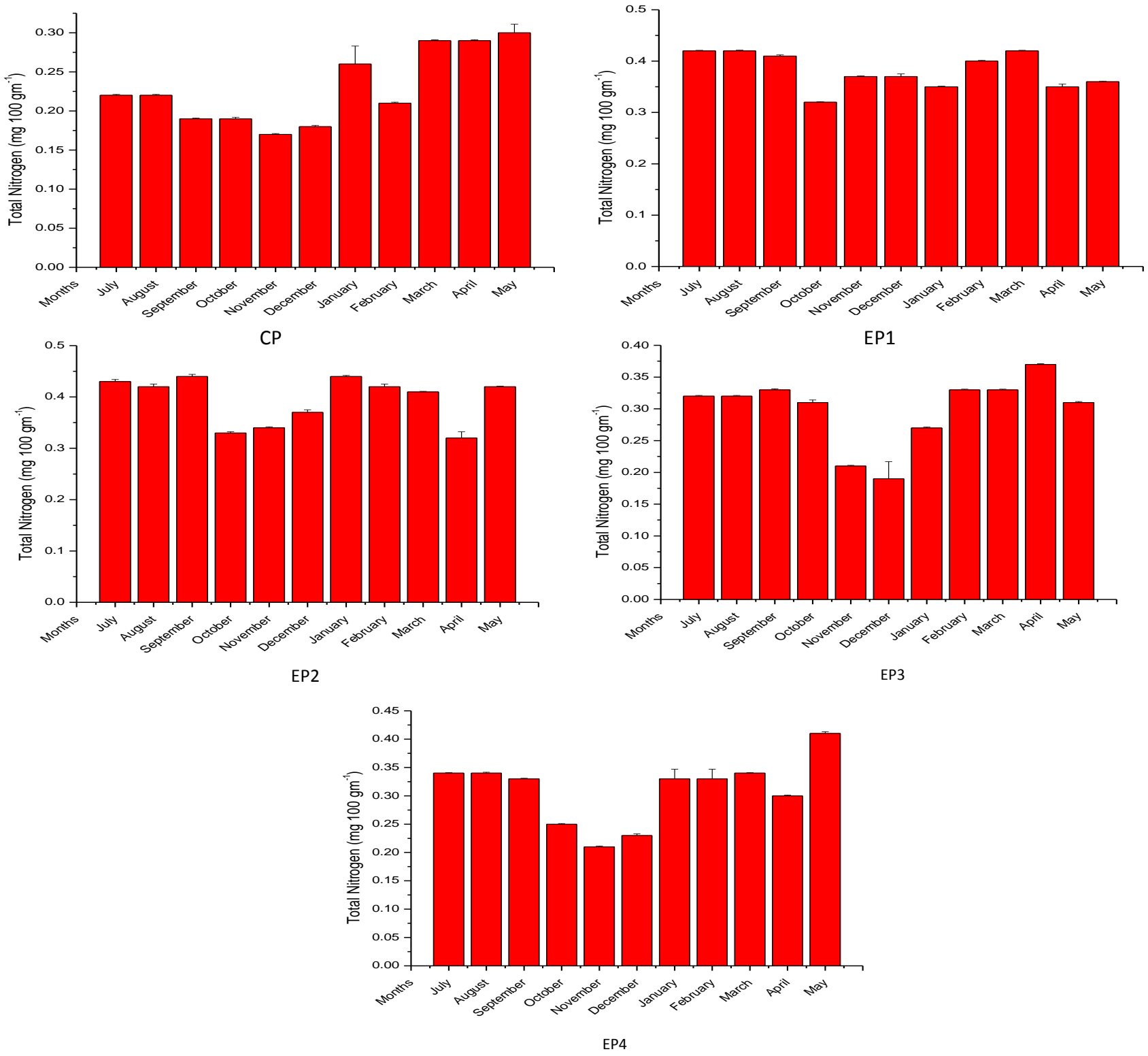

Figure 1. Total Nitrogen 
Results of Available Phosphorus (mg $100 \mathrm{gm}^{-1}$ ) season 2015- 2016:

In the month of July 2015 the available phosphorus was in CP pond 4.89, EP1 pond 6.28, EP2 pond 5.29, EP3 pond $4.94 \&$ EP4 pond 5.02. The available phosphorus in the month of August was in CP pond 4.06, EP1 pond 5.33, EP2 pond 5.32, EP3 pond $4.94 \&$ EP4 pond 5.07. In the month of September the available phosphorus was in CP pond 4.01, EP1 pond 5.24, EP2 pond 5.24, EP3 pond 5.17 \& EP4 pond 5.02. The available phosphorus in the month of October was in $\mathrm{CP}$ pond 4.02 , EP1 pond 5.13, EP2 pond 5.17, EP3 pond $4.93 \&$ EP4 pond 5.06. In the month of November the available phosphorus was in CP pond 4.69, EP1 pond 5.93, EP2 pond 5.84 , EP3 pond 4.92 \& EP4 pond 4.92. The available phosphorus in the month of December was in CP pond $4.65, \mathrm{EP} 1$ pond $4.92, \mathrm{EP} 2$ pond $4.91, \mathrm{EP} 3$ pond 4.88 \& EP4 pond 4.88. In the month of January 2016 the available phosphorus was in CP pond 4.65, EP1 pond 5.92, EP2 pond 5.94, EP3 pond $5.00 \& \mathrm{EP} 4$ pond 4.94. In the month of March the available phosphorus was in CP pond 4.02, EP1 pond 5.17, EP2 pond 5.76, EP3 pond 5.03 \& EP4 pond 4.83. The available phosphorus in the month of April was in CP pond 4.82 EP1 pond 6.07, EP2 pond 5.03, EP3 pond $4.96 \&$ EP4 pond 4.99. In the month of May 2016 the available phosphorus was in CP pond 4.09, EP1 pond 4.94, EP2 pond 6.97, EP3 pond $5.02 \&$ EP4 pond 4.98. In the month of July, 2015 the average available phosphorus was $5.284 \mathrm{mg}$. The average available phosphorus was $4.944 \mathrm{mg}$ in the month of August. In the month of September the average available phosphorus was $4.936 \mathrm{mg}$. the average available phosphorus was $4.862 \mathrm{mg}$ in the month of October. In the month of November the average available phosphorus was $5.26 \mathrm{mg}$. The average available phosphorus was $5.29 \mathrm{mg}$ in the month of January, 2016. In the month of February the available phosphorus was $5.326 \mathrm{mg}$. The average available phosphorus was 4.962 in the month of March. In the month of April the average available phosphorus was $5.174 \mathrm{mg}$. The average available phosphorus was $5.2 \mathrm{mg}$ in the month of May, 2016. The highest average available phosphorus was $5.326 \mathrm{mg}$ in the month of February, 2016 and the lowest average available phosphorus was $4.862 \mathrm{mg}$ in the month of October, 2015. In Ghat pond (CP) the highest available phosphorus was $4.89 \mathrm{mg}$ in the month of July and lowest available phosphorus was 4.01 in the month of September. In Dhara pond (EP1) maximum available phosphorus was $6.97 \mathrm{mg}$ in the month of February, 2015 and minimum available phosphorus was $4.92 \mathrm{mg}$ in the month of December. In Majari pond (EP2) highest number of available phosphorus was 6.97 in the month of May and lowest number of available phosphorus was $4.78 \mathrm{mg}$ in the month of February. In Nandan pond (EP3) maximum number of available phosphorus was $5.17 \mathrm{mg}$ in the month of September and minimum available phosphorus was $4.88 \mathrm{mg}$ in the month of December, 2015. In Masanta pond (EP4) the highest number of available phosphorus was 5.08 $\mathrm{mg}$ in the month of February and lowest number of available phosphorus was $4.83 \mathrm{mg}$ in the month of March, 2016.

Table 2. available phosphorus (mg $\left.100 \mathrm{gm}^{-1}\right)$.

Season (2015 - 2016):

\begin{tabular}{|l|l|l|l|l|l|}
\hline Months & CP & EP1 & EP2 & EP3 & EP4 \\
\hline July & 4.89 & 6.28 & 5.29 & 4.94 & 5.02 \\
& \pm 1.013 & \pm 0.008 & \pm 0.009 & \pm 0.015 & \pm 0.026 \\
\hline August & 4.06 & 5.33 & 5.32 & 4.94 & 5.07 \\
& \pm 0.018 & \pm 0.014 & \pm 0.006 & \pm 0.016 & \pm 0.011 \\
\hline September & 4.01 & 5.24 & 5.24 & 5.17 & 5.02 \\
& \pm 0.0012 & \pm 0.02 & \pm 0.018 & \pm 0.007 & \pm 0.022 \\
\hline October & 4.02 & 5.13 & 5.17 & 4.93 & 5.06 \\
& \pm 0.006 & \pm 0.022 & \pm 0.014 & \pm 0.009 & \pm 0.0253 \\
\hline November & 4.69 & 5.93 & 5.84 & 4.92 & 4.92 \\
& \pm 0.007 & \pm 0.018 & \pm 0.011 & \pm 0.007 & \pm 0.013 \\
\hline December & 4.65 & 4.92 & 4.91 & 4.88 & 4.88 \\
& \pm 0.009 & \pm 0.017 & \pm 0.012 & \pm 0.025 & \pm 0.004 \\
\hline January & 4.65 & 5.92 & 5.94 & 5.00 & 4.94 \\
& \pm 0.011 & \pm 0.012 & \pm 0.012 & \pm 0.004 & \pm 0.011 \\
\hline February & 4.72 & 6.97 & 4.78 & 5.08 & 5.08 \\
& \pm 0.014 & \pm 0.016 & \pm 0.012 & \pm 0.033 & \pm 0.025 \\
\hline March & 4.02 & 5.17 & 5.76 & 5.03 & 4.83 \\
& \pm 0.023 & \pm 0.036 & \pm 0.023 & \pm 0.02 & \pm 0.021 \\
\hline April & 4.82 & 6.07 & 5.03 & 4.96 & 4.99 \\
& \pm 0.021 & \pm 0.036 & \pm 0.018 & \pm 0.0092 & \pm 0.012 \\
\hline May & 4.09 & 4.94 & 6.97 & 5.02 & 4.98 \\
& \pm 0.004 & \pm 0.016 & \pm 0.013 & \pm 0.0123 & \pm 0.004 \\
\hline
\end{tabular}



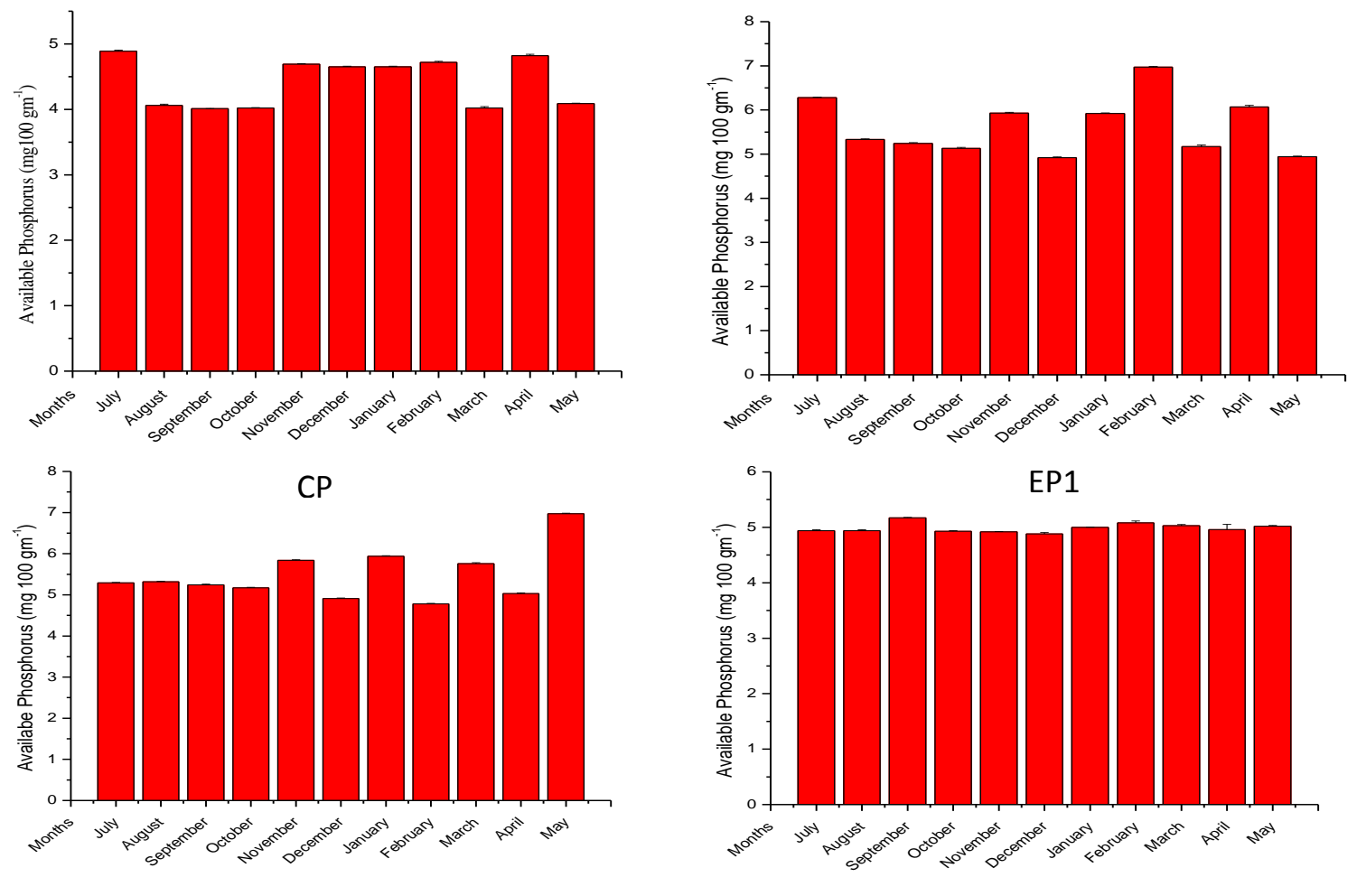

EP2

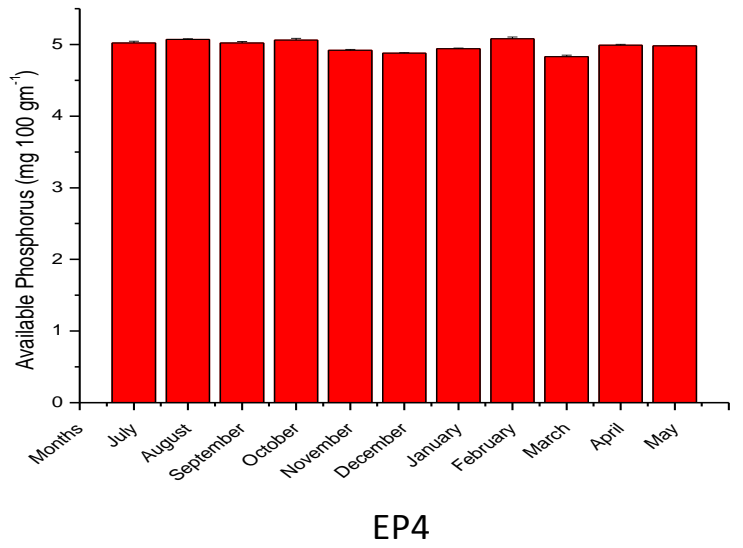

Figure 2. available phosphorus.

\section{Results of Available Potassium $\left(\mathrm{mg}_{100 \mathrm{gm}^{-1}}\right)$ season 2015- 2016:}

In the month of July 2015 the available potassium was in CP pond 1.85, EP1 pond 3.12, EP2 pond 3.03, EP3 pond 2.97 \& EP4 pond 2.83. The available potassium in the month of August was in CP pond 1.75, EP1 pond 2.97, EP2 pond 2.96, EP3 pond $3.03 \&$ EP4 pond 2.91. In the month of September the available potassium was in CP pond 1.76, EP1 pond 2.60, EP2 pond 2.63, EP3 pond 2.55 \& EP4 pond 2.56. The available potassium in the month of October was in CP pond 1.92, EP1 pond 3.11, EP2 pond 3.11, EP3 pond 3.05 \& EP4 pond 3.06. In the month of November the available potassium was in CP pond 2.15, EP1 pond 3.10, EP2 pond 3.42, EP3 pond 2.83 \& EP4 pond 2.83. The available potassium in the month of December 2015 was in CP pond 1.87, EP1 pond 2.33, EP2 pond 2.83, EP3 pond $2.28 \&$ EP4 pond 2.31. In the month of January 2016 the available potassium was in $\mathrm{CP}$ pond 1.82, EP1 pond 2.73, EP2 pond 2.80, EP3 pond 2.62 \& EP4 pond 2.66. The available potassium in the month of February was in CP pond 2.02, EP1 pond 3.94, EP2 pond 4.01, EP3 pond $3.53 \&$ EP4 pond 3.44 . In the month of March the available potassium was in CP pond 2.13, EP1 pond 3.83, EP2 pond 4.09, EP3 pond 3.78 \& EP4 pond 3.73 . The 
available potassium in the month of April was in CP pond 2.16, EP1 pond 3.34, EP2 pond 3.53, EP3 pond 3.03 \& EP4 pond 2.96. In the month of May 2016 the available potassium was in CP pond 2.07, EP1 pond 2.61, EP2 pond 2.86 , EP3 pond 2.86 \& EP4 pond 2.73. In the month of July, 2015 the average available potassium was $2.76 \mathrm{mg}$. The average available potassium was $2.724 \mathrm{mg}$ in the month of August. In the month of September the average available potassium was $2.42 \mathrm{mg}$. The average available potassium was $2.82 \mathrm{mg}$ in the month of October. In the month of November the average available potassium was $2.866 \mathrm{mg}$. The average available potassium was $2.324 \mathrm{mg}$ in the month of December. In the month of January, 2016 the average potassium was $2.526 \mathrm{mg}$. In the month of February the average available potassium was $3.388 \mathrm{mg}$. The average available potassium was $3.502 \mathrm{mg}$ in the month of March. In the month of April the average available potassium was 3.004 $\mathrm{mg}$. The average available potassium was $2.626 \mathrm{mg}$ in the month of May. In the year (2015-16) the highest average available potassium was $3.502 \mathrm{mg}$ in the month of March and lowest average available potassium was $2.324 \mathrm{mg}$ in the month of December, 2015 (table no-5.9.A.). In Ghat pond (CP) the maximum available potassium was $2.15 \mathrm{mg}$ in the month of November, 2015 and minimum available potassium was $1.75 \mathrm{mg}$ in the month of August, 2015. In Dhara pond (EP1) the highest available potassium was $3.94 \mathrm{mg}$ in the month of February and lowest available potassium was $2.66 \mathrm{mg}$ in the month of September, 2016. In Majari pond (EP2) the maximum available potassium was $4.09 \mathrm{mg}$ and SE \pm 0.016 in the month of March, and minimum available potassium was $2.63 \mathrm{mg}$ and $\mathrm{SE} \pm 0.009$ in the month of September. In Nandan pond (EP3) the highest available potassium was $3.78 \mathrm{mg} \& \mathrm{SE} \pm 0.066$ in the month of March and lowest available potassium was $2.28 \mathrm{mg} \& \mathrm{SE} \pm$ 0.008 in the month of December. In Masanta pond (EP4) the maximum available potassium was $3.73 \mathrm{mg} \& \mathrm{SE} \pm 0.012 \mathrm{in}$ the month of March and minimum available potassium was $2.31 \mathrm{mg} \& \mathrm{SE} \pm 0.029$ in the month of December.

Season $(2015$ - 2016):

\begin{tabular}{|l|l|l|l|l|l|}
\hline Months & CP & EP1 & EP2 & EP3 & EP4 \\
\hline July & 1.85 & 3.12 & 3.03 & 2.97 & 2.83 \\
& \pm 0.010 & \pm 0.011 & \pm 0.012 & \pm 0.010 & \pm 0.012 \\
\hline August & 1.75 & 2.97 & 2.96 & 3.03 & 2.91 \\
& \pm 0.012 & \pm 0.008 & \pm 0.03 & \pm 0.012 & \pm 0.005 \\
\hline September & 1.76 & 2.60 & 2.63 & 2.55 & 2.56 \\
& \pm 0.007 & \pm 0.005 & \pm 0.009 & \pm 0.013 & \pm 0.0189 \\
\hline October & 1.92 & 3.11 & 3.11 & 3.05 & 3.06 \\
& \pm 0.010 & \pm 0.007 & \pm 0.017 & \pm 0.022 & \pm 0.014 \\
\hline November & 2.15 & 3.10 & 3.42 & 2.83 & 2.83 \\
& \pm 0.010 & \pm 0.009 & \pm 0.011 & \pm 0.012 & \pm 0.013 \\
\hline December & 1.87 & 2.33 & 2.83 & 2.28 & 2.31 \\
& \pm 0.013 & \pm 0.011 & \pm 0.087 & \pm 0.008 & \pm 0.029 \\
\hline January & 1.82 & 2.73 & 2.80 & 2.62 & 2.66 \\
& \pm 0.012 & \pm 0.016 & \pm 0.006 & \pm 0.013 & \pm 0.007 \\
\hline February & 2.02 & 3.94 & 4.01 & 3.53 & 3.44 \\
& \pm 0.011 & \pm 0.015 & \pm 0.012 & \pm 0.015 & \pm 0.013 \\
\hline March & 2.13 & 3.83 & 4.09 & 3.78 & 3.73 \\
& \pm 0.011 & \pm 0.012 & \pm 0.016 & \pm 0.066 & \pm 0.012 \\
\hline April & 2.16 & 3.34 & 3.53 & 3.03 & 2.96 \\
& \pm 0.01 & \pm 0.0222 & \pm 0.010 & \pm 0.018 & \pm 0.008 \\
\hline May & 2.07 & 2.61 & 2.86 & 2.86 & 2.73 \\
& \pm 0.019 & \pm 0.012 & \pm 0.067 & \pm 0.116 & \pm 0.011 \\
\hline
\end{tabular}



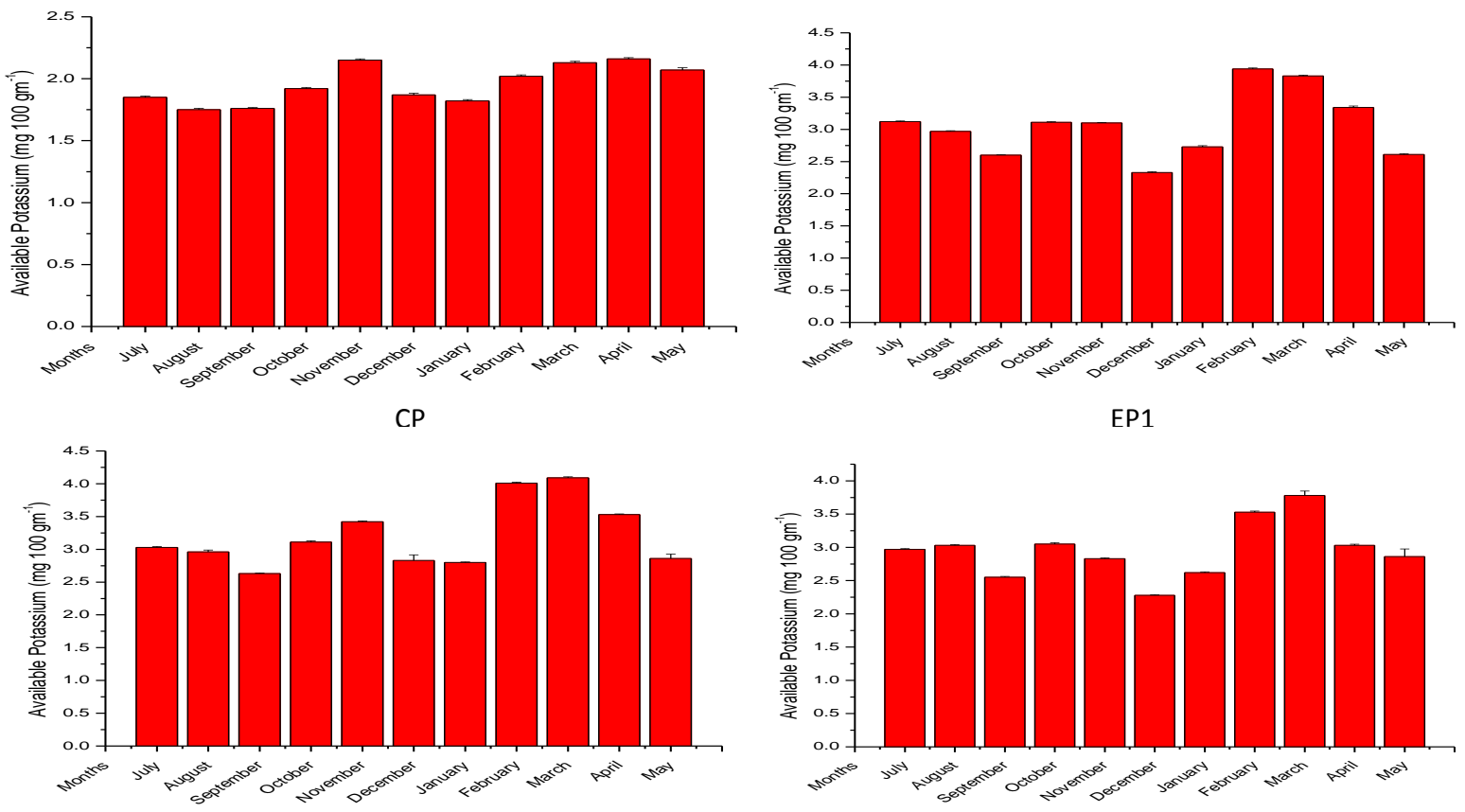

EP2

EP3

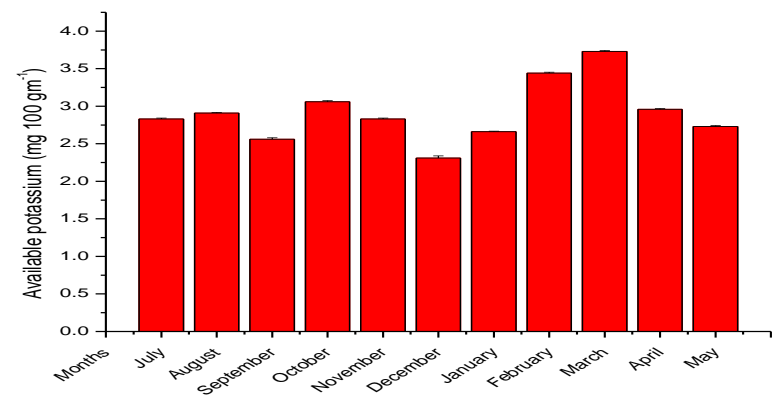

EP4

Figure 3. available potassium.

\section{Overall discussion on soil analysis in the Sabang block} areas, West Bengal, India:

It is known that in chemical characteristics of soil analysis affect the pond productivity. The nature soil reflects the nature of water (Dutta \& Kar, 1947). The characteristics of soil have been already dealt. The chemical characteristics which are involved in point productivity as well as fish production is reflecting in the discussion below.

Soil plays a key role in determining the productivity of pond. The chemical features of pond soil (mainly bottom soil) like N.P.K. act as important factors in influencing fertility and productivity of a fish pond (Wrobel, 1967; Patra \& Roy, 1988a; Patra, 1933). In order to find out the effectiveness of bacterial suspension (periphyton and denitrifying) in improving soil fertility. During the experimental period emphasis was given on N.P.K. as these are the important factors influencing the production of plankton (phytoplankton and zooplankton).

It has been observed that the level of nitrogen was $0.33 \mathrm{mg}$ $100 \mathrm{gm}^{-1}$ in EP1, 0.03 in EP2, 0.22 in EP3, 0.22 in EP4. In all the experimental ponds before treatment however, after treatment the nitrogen level increased considerable. After treatment higher value was 0.42 in EP1, 0.45 in EP2, 0.36 in EP3, 0.41 in EP4 and 0.29 in CP in the first year and in the second year it was 0.41 in EP1, 0.42 in EP2, 0.40 in EP3, 0.40 in EP4 and 0.28 in CP. The table indicates that the level of nitrogen is comparatively higher in periphyton treated ponds than that is denitrifying bacterial population treated ponds but the nitrogen in all of these experimental ponds is higher than that is control pond. This indicates that the bacterial suspension have the capacity in raising the level of nitr5ogen in soil which plays a part in improving the 
productivity of fish pond which effects the production of fish.

Phosphorus plays significant role in enhancing the productivity of pond. It is the most critical single element which limits productivity and there exist a correlation between the available soil phosphorus and fish production. In a productive pond the soil phosphorus according to Saha et al; (1979) should be above 4-6 mg $\mathrm{p}^{205} 100 \mathrm{mg}^{-1}$ but in unproductive it is below $3 \mathrm{mg} \mathrm{p}^{205} 100 \mathrm{mg}^{-1}$ of soil. Dennid McIntosh et al; (2000) stated that the level of phosphorus in pond soil is increased during the time of bacterial suspension. In this work it has been found that in the entire experimental pond phosphorus level move up considerably after treatment. In the first year of experimental trial the phosphorus level highest 6.91 in EP1 \& EP2, 5.17 in EP3, 5.08 in EP4, 4.91 in $\mathrm{CP}$ and in the second year highest value was 6.91 in EP2, 6.81 in EP1, 5.14 in EP3, 5.11 in EP4 \& 4.89 in $\mathrm{CP}$. The results indicate that the efficiency of the used bacterial population along with semidried cow dung is raising the level of available phosphorous of the soil. However, periphyton bacterial population proved to be relatively more powerful in raising the phosphorus level and consequently enhancing the production of fish. Denitrifying bacterial population also avowed better than result obtained from (CP) only treated with semi-died cow dung. Although the phosphorus level was lower in all the experimental ponds as has been by Dennis McIntosh et al; (2000).

Potassium is not limiting factor and is not necessary to increase production. Though it ranks as major nutrient element along with nitrogen and phosphorus it importance is observed (Banerjee, 1972; Ghosh, 1978).

Water quality is an important indicator in appraising the eutrophic situation; primary productivity and fish yield potential. The relationship between bacteria and he water environment has received the attention of researchers, but the studies undertaken have been mostly limited to the relationship between the aerobic heterotrophic bacteria and the water environment Guo et al; 1988; Fang et al; 1989; Liu et al; 1992a. There is not much information on the major physic-chemical factors and growth in fish particularly periphyton bacteria affecting population.

\section{CONCLUSION AND FUTURE SCOPE}

Study on soil analysis in ponds in the Sabang block areas, West Bengal, India is scanty. But it has to be tremendous economic significance and relevance aquaculture practice which is likely to open new vistas pertaining to the sustainable development. So the objective of the study was too evaluated of the routine use of a commercially and naturally improvement of soil quality of ponds. So, nitrogen, phosphorus, potassium in the year of experiments was in no way unfavorable for the growth of the carps.
Future scope is free hygienic fishes production in ponds.

\section{ACKNOWLEDGMENT}

I am grateful to Dr. Balaram Das of Belda College, Sujoy Sarkar (Librarian), Achyutananda Mandal, Niloy Biswas, Ranjit Basak, Kajal Hazra of Balurghat B.Ed. College, Dakshin Dinajpur, W.B. for supporting necessary materials, guidance and my parents (Bhagbat Ch. Maji, Alpana Maji) and my wife (Dipika Maji) for support this work.

\section{REFERENCES}

[1]. Anant J. Dhembare, Statistical approaches for computing diversity and density of Zooplankton with water factor in Mula dam, Rahuri, M.S. European Journal of Experimental Biology, 1(2): 68-76 ISSN: 2248-9215, 2011.

[2]. AOAC, Official Methods of Analysis, $13^{\text {th }}$ ed. Association of Official Analytical Chemists. Washington D.C. 376-384, 1980.

[3]. Arivozhagan, P. And Kamalayeni, K., Seasonal variation in physic chemical parameters and plankton analysis of Kurichi pond. J. of Environ and Ecol. 15(2): 272-274, 1997.

[4]. Barbaruah AD, Phukan SS, Dutta A, A comparative study of impact of water and soil quality on fish diversity of Monoha beel and Elenga beel of Morigaon, India. The Clarion 1:94-100, 2012.

[5]. Barret, P., Potassium concentration in fertilized trout lakes. Limnol. Oceanogr. 26: 55-59, 1957.

[6]. Bhatnagar, A., Devi, P., Water quality guidelines for the management of pond fish culture.International journal of environmental sciences volume 3 (6), 1980 - 2009, 2013.

[7]. Bora S, Biswas SP, Water quality and ichthyofaunal diversity of an oxbow lake in upper Assam. Int. j. fish. aquat. stud. 3: 15-18, 2015.

[8]. Cascallar, L; Mastranduono, P; Mosto, P; Rheinfeld, M; Santiago, J; Tsoukalis, C; Wallace, S. Periphytic algae as bioindicators of nitrogen inputs in lakes. Journal of Phycology. Vol. 39, no. 1, pp. 7-8, 2003.

[9]. Correl, D.L., The role of phosphorus in the Eutrophication of receiving waters, a review. J. Environ quality (USA). 27(2): 261266, 1998.

[10]. Ghose, K.C., and Manna, B. Practical Zoology, New Central Book Agency (P) LTD, Kolkata, 2009.

[11]. Gomez, K.A. \& Gomez, A.A, Statistical Procedures for Agricultural Research $2^{\text {nd }}$ Education. John Wiley and Sons, New York, 680p, 1984.

[12]. Guo A., Vulchanova L., Wang J., Li X., Elde R, Immunocytochemical localization of the vanilloid receptor 1 (VR1): relationship to neuropeptides, the $\mathrm{P}_{2} \mathrm{X}_{3}$ purinoceptor and $\mathrm{IB}_{4}$ binding sites. Eur J Neurosci. 1999; 11: 946-958.

[13]. Hargreaves, J.A, Nitrogen biogeochemistry of aquaculture ponds. - Aquaculture., 166, 181 - 212, 1998.

[14]. Hargreaves, J.A., and Tucker, C.S. Managing Ammonia in Fish Pond.- Southern Regional Aquaculture center., no. 4603, 1 - 8, 2004.

[15]. Horrigan, S.G., and Springer, A.L. Ocenic and esturine ammonium oxidation effects of light. Limnol Oceanogr 35: 479$482,1990$.

[16]. Jagadeeshappa KC, Kumara V, Influence of physico-chemical parameters on the diversity of plankton species in wetlands of Tiptur taluk, Tumkur dist, Karnataka State, India. Carib.j.SciTech. 1:185-193. 2013. 
[17]. Kjedscn. K. The relationship between phosphorus and peak biomass of benthic algac in small lowland strems. Verh. Int. Ver. Limmol. 25: 1530-1533, 1994.

[18]. Kumari, V., Rathore, G., Chauhan, U.K., Panday, a.k., and Lakra, W. S. Seasonal variations in abundance of nitrifying bacteria in fish pond ecosystem. - Journal of environmental Biology. 32, 153 - 159, 2011.

[19]. Marinelarena, AJ; Di Giorgi, HD. Nitrogen and phosphorus removal by periphyton from agricultural wastes in artificial streams. Journal of Freshwater Ecology. Vol. 16, no. 3, pp. 347354, 2001.

[20]. Olila, O. G., Reddy, K. R. and Harris, W. G., Forms and Distribution of inorganic phosphorus in sediments of two shallow eutrophic lakes in Florida. Hydrobiologia. 302: 147-161, 1995.

[21]. Patralekh, L.N. Comparative account of physico -chemical properties of three freshwater ecosystems. J. Freshwater Bioi. 6: 115-119, 1994

[22]. Singh, H.P. Distribution and seasonal fluctuation of certain physico-chemical features in the Brahmaputra river. J. Assam Sci. Soc. 32: 64-69, 1990.

[23]. Sinha, A.K., Baruah, A., Singh, D.K. and Sharma, U.P. Biodiversity and pollutional status in relation to physico-chemical factors of Kawar Lake wetland (Begusarai), North Bihar. J. Freshwater Bioi. 6: 309- 315, 1994.

[24]. Sudhira, H. S.; Kumar, V. S. Monitoring of lake water quality in Mysore city, proceedings of Lake 2000. International symposium on restoration of lakes and wetlands, $27-29$ Nov.
2000, CSIC Auditorium, Indian Institute of Science, Bangalore, (2000), 1-10.

[25]. Thapa Chetry D, Pal J, Physico-chemical parameters of Koshi river at Kushaha area of Koshi tappu wildlife reserve. Our Nat. 9: 156-167, 2011.

[26]. Tiwari, T. N. and Manzoor, A., Ground water of Nuzrid Town: Regression and chemical analysis of water quality parameters, Indian Journal of environmental protection. 9(1): 13-38, 1989.

[27]. Vao, H., Wang, H., He, S., Ou, R., Hou, S., and Yong, X. Isolation and characterization of a denitrifying Acinetobacter baumannii H1 using $\mathrm{NO} 2$ - $\mathrm{N}$ as nitrogen source from shrimp farming ponds.- African journal of Microbiology Research., vol. 6, pp. $2258-2264,2012$.

[28]. Vora, A. B., Ahluwalia, A. A., Gupta, R. Y., Study on water and soil, vegetation, zooplnktona and zoo-benthos. In: Environmental Impact Assessment of Sardar Sarovar Project on Nalsarovar Bird Sanctuary, Gujarat. Ecological Education and Research (GEER) Foundation, Gandhinagar, 1998.

[29]. Wielgosz, E., Jozwiakowski, K., and Bielinskar, E.J. Number of Ammonifying, Nitrifying and Denitrifying bacteria in sewage treated in a system of biological stabilization ponds. - Teka Kom. Ochr. Kszt. Srod. Przyr. - OLPAN., 7, 446 - 456, 2010.

[30]. William, A. W \& Robert, M. D. Interactions of $\mathrm{pH}$, Carbon Dioxide, Alkalinity and hardness in Fish Ponds, SRAC Publication No. 464:1-4.

[31]. Worbel, S. (1967). FAO Fish. Rep. 44(3), 153-163, 1992.

[32]. Zutshi, D. P. and Vass, K., Variation in water Quality of Kashmir lakes. Trop. Ecol. 14: 182-196, 1973. 